\title{
NOTES ON THE NATIVE FLORA OF NEW SOUTH WALES.
}

By R. H. Cambage.

\begin{abstract}
Part iv. The Occurrence of Casuarina stricta Ait., on the Narrabeen Shales.
\end{abstract}

(Plates xii.-xiii.)

The occurrence of Casuarina stricta Ait. (C. quadrivalvis. Labill.) near Sydney is a matter of considerable interest both from a geological and botanical standpoint.

This species is often known as She-oak and sometimes as Mountain Oak; and although it cannot be said to grow into large trees, being usually about 20 feet high, its shapely rounded head and pendulous habit render it a very graceful and picturesque member of our native flora. It is a common tree on many of the hills throughout the western districts of New South Wales, and is recorded from various localities in Victoria, South Australia, Western Australia and Tasmania. It may be seen from several points on the railway line between Albury and Melbourne, between Melbourne and Adelaide, and also between Launceston and Hobart, being common on the igneous formation around the former, especially near The Gorge. In my 'Notes on the Botany of the Interior of New South Wales' (these Proceedings 1900-1902) it has been recorded under the name of C. quadrivalvis Labill., from many localities extending from Cobar, Nymagee, Mount Hope, Condobolin, Trundle, Forbes, Wyalong, Cootamundra to Junee; and by others from the Mudgee and Goulburn River districts south-westerly. It occurs at Mount McDonald (on granite), Wagga, Tumut and Gundagai, being formerly very conspicuous on a hill east of Coolac. It has been recorded from South-eastern New South Wales; and specimens in the National Herbarium, 
Sydney, show, in addition, that it has been found at Jervis Bay, and on the eastern side of the Liverpool Range on the Upper Hunter, having come across from the west to the latter locality in company with other western plants.

Although the species is fairly common in the cool climate of Tasmania, yet in New South Wales it appears to flourish more in the warm interior than on the cold highlands, in which feature it differs altogether from the majority of species which occur in both the States mentioned. In New South Wales we usually find the representatives of the Tasmanian flora along or close to the Great Dividing Range, though some follow at lower levels along the coastal area; but in my experience $C$. stricta has. seldom been found at an altitude exceeding 2000 feet above sealevel, and in the western districts may be seen more often at elevations below 1500 feet. In descending the western slopes from the Blue Mountains, it does not become common till the White Box (Eucalyptus albens Miq.) country is almost crossed, and it then continues intermittently through the remainder of that zone of country, extending beyond to the dryer areas around Nymagee and Mount Hope, and in fact through South and Western Australia.

In Western New South Wales it has a distinct preference for growing on the tops of hills, which thereby suggests the name of Mountain Oak; and in many cases these hills are so isolated that there may be 10 or 20 miles of forest land intervening without a solitary tree of this species to be found. In studying the distribution of the species, this seems to be a point which should be kept in view, for it is somewhat suggestive of the species being a remnant of what previously had a more continuous range. From observations made in the western districts it appears to favour hills of igneous origin, especially porphyry, but is by no means restricted to that formation, as it occurs on several isolated sandstone peaks, probably of Devonian age, one in particular being the Pinnacle, south of Forbes, while others are the Weddins, west of Grenfell. It certainly seems to avoid the Hawkesbury Sandstone of the coastal area. A remarkable instance of partiality, 
however, may be noticed near Mount Hope, where it occurs plentifully on a rounded porphyry hill known as Mount Allen; while on Double Peak, only four miles away, but which is chiefly of Silurian(?) slate formation, not a single She-oak can be found. Another characteristic of the species is that it seems to select spots on hills that are otherwise fairly clear, and it apparently objects to grow in forests under the shelter of larger trees. In this way it makes itself fairly conspicuous, and its rounded pendulous form becomes a notable feature on some of these clear and rather bald hill-tops. It is a prolific fruiter, some of the trees being literally covered with cones (Plate xii.).

Its qualities as a fodder plant are, however, so far as New South Wales is concerned, causing it to be exterminated from many of the western hills, and in some cases the only traces now to be found consist of the large somewhat cylindrical cones, at times up to two inches long, lying scattered about on the ground, while the remaining stumps, with their conspicuous medullary rays, are standing as sentinels beside the fallen and decaying branches.

Its very wide distribution over Western and Southern Australia, including Tasmania, and its being now able to grow under so many different conditions of climate, suggest that it is a species of great antiquity, probably antedating the time when Tasmania ceased to be connected with the mainland.

Recently I found it growing over a small area on the Narrabeen Shale formation near Newport, at about a dozen miles north of the entrance to Port Jackson; and this is the most northern locality recorded for the species on the eastern coast of Australia.

To thoroughly appreciate the significance of this discovery, it is necessary to first understand the disposition of these Narrabeen Beds. This formation consists of shales and sandstone which were laid down as sediment in the early Triassic period. In its upper part is a band of fine chocolate-coloured shales, and it has been suggested by Professor David* that they have probably

* Anniversary Address to the Royal Society of New South Wales, May, 1896. Journ. Proc. Roy. Soc. N. S. Wales, xxx. 1896. 
derived their colouring from the oxidation of magnetite contained in fine volcanic tuff interstratified with the shales. They extend approximately from about Maitland in the north to the westward of Kiama in the south, and near Lithgow in the west, though their north-western extent is not at present definitely defined; and they are overlaid throughout by a considerable thickness of Hawkesbury Sandstone, which in the Parramatta to Penrith, Picton and surrounding districts is again covered by the Wianamatta Shales. Towards the edges of the above first-mentioned area the chocolate shales thin out, and in some cases have been so denuded as well, that they only appear as reddish-brown bands in the face of the cliffs, particularly on the Blue Mountains or on the talus slopes of ridges capped by Hawkesbury Sandstone; and while having little or no influence on the surrounding vegetation, they afford a splendid geological horizon for the correlation of adjacent rocks. Owing to subsidence of the central part of the coal basin west of Sydney, the Narrabeen Series are found to have dipped from above sea-level at Narrabeen to nearly 900 feet below sea-level on the northern shore of Port Jackson, as proved by the first Cremorne bore. They rise again, however, on the southern side of the basin, and reappear on the coast to the north-east of Otford, nearly 30 miles southerly from the entrance to Port Jackson. That they rise again to the eastward in the Sydney district is shown by the fact that at The Sydney Harbour Collieries' shaft at Balmain the Chocolate Shales are about 950 feet below sea-level, while at the first Cremorne bore, which is situated about three miles to the eastward, they are met with at about 890 feet, though the strata are rising more rapidly to the eastward in this latter locality, as proved by the results of the first and second Cremorne bores. At these two before-mentioned extreme points, viz., Narrabeen to Newport on the north, and near Otford on the south, these shales are exposed to a greater extent than is commonly found in any other part of their area, the Hawkesbury Sandstone having been denuded; and it was owing to their exposure and the facilities thus afforded for their study in the northern area that the local name of Narrabeen 
Series was suggested by Mr. C. S. Wilkinson for this particular formation.

Now having in view the fact of their exposure at the two places mentioned, and that Casuarina stricta was not common on the coast of New South Wales excepting perhaps in the extreme south, and was really an inland tree, the finding of this species on this somewhat rarely exposed formation near Newport suggested the idea that it had probably wandered so far from its regular habitat owing to geological causes, there being no climatic reason why it should not also occur along the whole of the coast; and that therefore it might perhaps be successfully looked for on the similar formation at Otford. Before proceeding to search this locality, however, enquiries were made at the Botanic Gardens, where it was learned from Mr. J. H. Maiden that this plant was certainly growing near Otford, as both he and Mr. E. Betche had collected it there some years ago, though it had not been recorded.*

An unsuccessful search was subsequently made on the coast near Kincumber to the north of Broken Bay, and extending from Terragal Head to First Point, locally known as Winny; but although the formation is mapped as belonging to the Narrabeen Beds, the country is somewhat sandy from the disintegration of the sandstones in the district. The interesting fact was noticed, however, that, growing along the edge of the cliffs and over much of the headland known as First Point, the surface of which was composed of sandstone, with loose pebbles scattered at intervals, was another species of Casuarina, viz., C. distyla Vent., which was not found inland towards Gosford, though it is common enough on the Hawkesbury Sandstone formation around Port Jackson. What was apparently this same dwarf oak shrub could also be seen covering a considerable area on Second Point, about $1 \frac{1}{2}$ miles to the southward, the aggregation of male flowers giving

Postscript (added 26th October, 1905). - I have since been informed by Mr. A. G. Hamilton that C. stricta is growing near Mt. Kembla. This extends its range about 20 miles southerly from Stanwell Park but still on the exposed strip of Narrabeen Shales. 
the headland quite a brown appearance. It may be mentioned that this locality is the most northern coastal spot recorded for C. distyla, though it extends north-westerly a considerable distance inland, following the Triassic formation.

Although the occurrence of C. stricta at Newport and Otford appears to indicate a preference for the particular local geological formation, it still remains a somewhat difficult matter to account for its being there at all. Its general habit as well as its wide and curious distribution on the hill-tops of the western districts appear to certainly point to the antiquity of the species; and if it could be shown that the Narrabeen Shales in prehistoric times had extended eastward from the present coast-line and were clothed with vegetation, it would seem quite possible that this Casuarina may have formed part of its flora; and these isolated patches now on the present coast are the remnants of this particular species, the greater part of which has been destroyed in the intermediate localities by the alteration of the shore-line. That the coast-line of New South Wales was formerly some 15 or 20 miles further eastward is regarded by geologists as almost beyond doubt (Plate xiii.).

The Rev. W. B. Clarke* suggested that "the eastern extension of Australia has been probably cut off by a general sinking."

Mr. C. S. Wilkinson, $\uparrow$ writing on the subject, and speaking of the present sea-floor within some 20 miles of the coast, says :"Here the bed of the ocean probably consists of the old land surface which once formed a continuation of that upon which the City of Sydney now stands and which has been faulted to a depth of over 12,000 feet. . . . . We have evidence that these faultings probably took place towards the close of the Tertiary epoch, for no marine Tertiary deposits are known along this portion of the coast of Australia, whereas in New Guinea and Victoria the marine Miocene beds occur at elevations up to eight

* Remarks on the Sedimentary Formations of New South Wales. Fourth Edition, 1878, p.7.

+ Mineral Products, etc., of New South Wales. 1882, p.52. 
hundred feet above the sea. . . . Had this low-lying country along the coast then existed it must have been covered by the Miocene sea. . . . But it is very probable that until or during the Pliocene period it stood at a much higher level, and extended some distance beyond the present coast-line. Then again the Tertiary deposits throughout east Australia show that the valleys draining the Great Dividing Range have been chiefly eroded since the Miocene period. . . . Therefore the sinking of the land traversed by any of these valleys, such as that of Port Jackson, evidently took place in comparatively recent geological times, and may have been contemporanenus with the extensive volcanic eruption of the Upper Pliocene period during which the southern portion of Victoria especially was the locale of great volcanic activity. How far this old land extended to the east it is difficult to indicate; but no doubt future observations upon the distribution of the marine and terrestrial fauna and flora of the South Pacific region will throw much more light upon the subject."

Professor David* also gives evidence to show that the Coalmeasures upon which the Narrabeen Shales are superimposed rise towards the eastward of Port Jackson, and it therefore follows that these shales must also have risen (evidence of which has already been given from the results of the Balmain shaft and Cremorne bore), and may in part have formed the eastern margin of the depression in which the Hawkesbury Sandstone was deposited. Subsequently to Triassic time continuous erosion and denudation would remove much of the Hawkesbury Sandstone from the eastern edge, thus exposing the Narrabeen Beds; and this formation, or the Permo-Carboniferous, or possibly the upturned edges of both, would remain exposed until the final subsidence, which is estimated to have occurred in late Pliocene or Post-Tertiary time. The extension of that former land-surface for some distance north and south, and possibly its eastern margin. also, would probably be composed of Permo-Carboniferous forma-

* Journ. and Proc. Roy. Soc. N.S.Wales. Vol.xxx, pp.43, 48, 69. 
tion similar to that at Jervis Bay, another point at which $C$. stricta has been found.

Evidence of submergence is given by Etheridge, David and Grimshaw* who state, amongst other matters, that at Shea's Creek near Sydney "there is evidence of an alteration in the level of the land and sea in recent geological time to the amount of about fifteen feet, as the trees found in situ by us at a depth of fifteen feet below high water all belong to genera which do not flourish below the level of high tide." . . . "The date . . . cannot therefore be moved back below the limits of the PostTertiary time. . . . It is questionable whether it is likely that the date can be carried back into Pleistocene time."

E. C. Andrews, B.A., refers to this coastal subsidence as PostTertiary, $\dagger$ and says :- " The movement is still youthful, as may be seen by a study of the cliffs between Port Jackson and Botany Bay, where the 250 feet walls end abruptly in 8 to 10 fathoms of water, thus showing that the formation of forelands and beaches in that locality is still distant in point of time."

Attention is drawn to the evidence already quoted in regard to marine Tertiary deposits, which goes to prove that the original continental shelf must have stood above sea-level at least till late Tertiary time; but this evidence does not show that the submergence may not have been delayed even until the Pleistocene period, although in Victoria the deposits are chiefly of Eocene and Miocene age. Possibly therefore it may not be necessary to prove such great antiquity for this Casuarina as would at first sight appear.

It may be noted that at each of the places mentioned, viz., Newport, Otford, and Jervis Bay, this tree has been found only within a short distance of the ocean, so that had the subsidence

- "On the Occurrence of a Submerged Forest with Remains of the Dugong at Shea's Creek, near Sydney." By R. Etheridge, Jr., Prof. David and J. W. Grimshaw. Journ. and Proc. Roy. Soc. N. S. Wales. Vol.xxx. pp.178, 179.

+ "Notes on the Geography of the Blue Mts. and Sydney District." Proc. Linn. Soc. N. S. Wales, 1903, pp.814, 815. 
and erosion extended westerly another mile or so, or less than a quarter of a mile at Newport, probably no trace of this species would be found to-day near either place.

If therefore we could have a living species which had existed from late or Post-Tertiary time, and evidence is available to show that such could happen, then it seems that the conditions are favourable to Casuarina stricta being such a species. That it is ancient is proved by its wide distribution and adaptability to varying conditions. Such Eucalypts as E. coriacea A. Cunn., $E$. amygdalina Labill., and E. viminalis Labill., are common to both Tasmania and New South Wales, but in the latter State their home is on the highest land. Not a single Eucalypt which is found in Tasmania is known to occur in the interior of New South Wales.

Bentham $\uparrow$ speaks of the Order Casuarineæ as a very distinct one, the remarkable vegetative characters having no nearer parallel than amongst some Coniferæ. Now the Natural Order Coniferæ is well known to be an ancient one. True Coniferæ are stated by Sir Archibald Geikie* to have been abundant in Carboniferous time, and evidence is recorded of their occurrence prior to that period.

The genus Casuarina is also regarded as an ancient one, and there are records of its having been found fossil in Tertiary, and possibly Cretaceous time, though the absolute identity of some of the Tertiary specimens has been questioned.

In describing the Potomac Formation, Lester F. Ward $\ddagger$ makes lengthy reference to a fossil plant, and after discussing the possibilities of its being a Casuarina, says:- "I have therefore decided upon the whole to refer this form to Casuarina, with all necessary reservation, and to name it, in honour of Mr. Coville, C. Covillei. It would certainly be an interesting fact if it were proved that this anomalous type of vegetation lived in America during Lower Cretaceous time."

* 'Flora Australiensis,' vi. 133.

† Text Book of Geology. Third Edition, p.811.

‡ Fifteenth Annual Report of the U.S. Geological Survey, 1893-94, p.353. 
A. Schenk, ${ }^{*}$ however, expresses some doubt, and exercises considerable caution in criticising fossil specimens of Casuarina described by Ettingshausen and Heer, and refers to fossils from Bilin figured by Ettingshausen as of less value as proof of the existence of the genus Casuarina in the European Tertiary, than those described by Heer, which are nothing but the remains of scarcely determinable twigs with opposite leaves. Heer's Sumatra specimens Schenk considers are of much greater value, even though the determination does not appear to him as absolutely definite.

From the Tertiary flora of New South Wales, Ettingshausen $\dagger$ has described a species of Casuarina found near Emmaville and named it C. Cookii. He describes the sheath-teeth as four in number, which, it may be pointed out, corresponds with the number found on C.torulosa Ait., a species common along the north-eastern coast of New South Wales to-day, and extending up along the eastern slopes of New England to within about 20 miles of where $C$. Cookii has been found.

Whether the existence of the genus Casuarina in Europe or America during Tertiary or Cretaceous time is ultimately proved or not does not seriously affect the question under discussion.

That plants have persisted from late Tertiary time to the present day is an acknowledged fact. Clement Reid, F.R.S., $\ddagger$ writing on the origin of the British Flora, regards the Preglacial period as latest Pliocene, and gives a list of plants including 57 genera and 75 species which are found fossil in the Preglacial period and are also living plants, all but three being still in Great Britain.

Other instances could be quoted; and the same persistence applies to the fauna as well.

It must also be remembered that new fossil plants are often necessarily described from very imperfect material, and although

* Traité de Paléontologie. Par Karl A. Zittel. Partie ii. Paléophytologie. A. Schenk, pp.396, 397.

† Contributions to the Tertiary Flora of Australia. Ettingshausen, p.107.

$\ddagger$ The Origin of the British Flora, 1899, p.52, and pp.171-179. 
the best available, it is at the same time often so meagre that sufficient comparison cannot be made with living specimens to decide whether or not the fossil and some living plant may not belong to the same species, the result being in many such cases that the fossil is described as a new species. Owing to force of circumstances, therefore, the question of the identity of fossil plants with living species is one that is not satisfactorily investigated, and even where differences are noted, the fossil may possibly be in some cases the ancestral form of a living plant.

In the case of $C$. Cookii found near Emmaville, the specimen is, according to the drawing, only a fragment of a branchlet, and from its diameter and number of sheath-teeth, there seems practically nothing to differentiate it from C. torulosa, which is flourishing to-day along much of the eastern coast of northern Australia.

As previously stated (supra) the occurrence of C. stricta in Tasmania as well as on the mainland goes very far to prove its existence while a land-connection extended from the former to Victoria. Dr. A. W. Howitt, who has closely studied the question of this land-connection, when dealing with the origin of the Aborigines of Tasmania, writes*:- "The commencement of this later connection of Tasmania and Victoria may be provisionally placed in the Pliocene epoch. What may have been its duration it is not possible to state within definite limits; but it may have been as late as the more recent volcanoes of south-western Victoria and the south-eastern district of South Australia."

Professor Ralph Tate $\dagger$ says of the latter that " they are newer than the Pliocene sand and loess which are interstratified between the Mount Gambier limestones and the ashbeds of that place."

"Leaves of Casuarina and Banksia are impressed on the under surface of the superimposed ash-layer."

It will therefore be seen that Wilkinson suggests that the subsidence along the coast of New South Wales may have been

* Presidential Address (Section F. Ethnology and Anthropology). Report Aust. Assoc. Adv. Sci. 1898, vii. p.741.

† Ann. Address, Trans. Philosophical Soc. Adelaide, 1878-9, p.lxix. 
contemporaneous with the volcanic eruption of the Upper Pliocene period; that Howitt places the latest land-connection between Tasmania and Victoria as possibly during that period of volcanic disturbance also; and that Tate considers this particular volcanic period to be newer than Pliocene, and to have occurred at a time when Casuarina and Banksia were growing in the south-eastern part of South Australia, and that the Aborigines probably witnessed the glow of internal fires from the cones of these volcanoes.

In these Proceedings for 1901 (pp.687, 688) I drew attention to some trees of Casuarina Cunninghamiana Miq. (River Oak) which are growing on a fresh-water creek near the head of Burrill Lake at Ulladulla, and no others being in the district, it was suggested (after discussion with Mr. J. J. Fletcher, B.Sc.) that these few were the deseendants of what had once been a greater number, extending perhaps some miles down the creek, which, owing to this coastal subsidence, had been nearly filled by the inflow of salt water, thus destroying all the fresh-water oak trees except those which were growing on this limited area.

The foregoing particulars are given to show the possibilities in regard to C. stricta having existed in Pleistocene or perhaps late Pliocene times; but what changes it may have undergone during that great lapse of time it is quite impossible to say. If it did not occur on these isolated coastal spots prior to the subsidence referred to, then its presence there to-day has to be otherwise accounted for.

The methods of distribution which most readily suggest themselves are those by ordinary growth of seedlings near the parent tree, by wind, birds and water.

In this instance the first mode can be ignored altogether, as the distance between Newport and Otford is about 40 miles, and so far as is known there is not a single tree of C. stricta anywhere between the two places; while three large sheets of water in Port Hacking, Botany Bay and Port Jackson would have to be crossed. 
The distribution by wind is also most unlikely owing to the distance, and also the fact that the air near the ocean is so heavily charged with moisture that small objects are unlikely to float very far. The only dry winds we have on the coast blow out to sea. In the hot and dry interior the conditions are different.

The possibility of seeds being carried by birds requires more serious consideration. It is well known that the seeds of this particular She-oak are eaten by birds of the Black Cockatoo family (Calyptorhynchus sp.), one known to many along the coast as a so-called Macaw being especially fond of them. I have seen this bird among these trees as far west as Nymagee, while on eastern New South Wales they are usually to be found on the Forest Oak (C.torulosa Ait). Clement Reid, F.R.S.,* gives an instance of his finding, in an old chalk pit, the remains of a pigeon which had met with an accident. Its crop was full of broad-beans which were growing, though under ordinary circumstances they would have been digested and destroyed. But although distribution occurs through the agency of birds, it must be borne in mind that $C$. stricta is a diœcious species, and ordinarily it would therefore be necessary for two trees to grow fairly close together, one bearing male and the other female flowers, before the propagation of the species could be accomplished. It would seem unreasonable, therefore, to look for any accidental dispersal of seeds, forty miles apart, answering the above conditions, and at the same time being placed respectively on the northern and southern outcrops of the Narrabeen Shales.

The cones of a Casuarina might certainly be carried by water, though the seeds would probably be destroyed by a lengthy immersion. The transporting agent in this case could only be the ocean, but compliance with the conditions mentioned above would probably be again necessary as regards the male and female trees. As the home of C. stricta is in the southern part of Australia, and it is not known to occur along the eastern coast of Northern

\footnotetext{
* Origin of the British Flora, p.30.
} 
Australia, it could only be brought to Otford and Newport from the south; but the prevailing ocean current in the vicinity of these places is from the north. Mr. G. H. Halligan, F.G.S., Hydrographic Surveyor, Public Works Department, who has made a special study of these currents, writes to me as follows"It is certain that the N.E. current coming through Bass' Straits, and which would become a northerly current if it skirted the east coast of Australia, never reaches much further north than Twofold Bay, except perhaps as an undercurrent. It seems to me quite impossible that $C$. stricta can have been conveyed by water from the southern coast as far north as Jervis Bay." It might also be mentioned that near Otford the species is confined to the upper part and sides of the hills, and does not extend to the low land near the ocean. The same remark applies to Newport, though there the sloping hill approaches nearer the ocean at one spot; so that if the seeds were washed ashore the available evidence indicates that they would still have to be carried to the hillside before young plants would grow.

Looking at the matter from any point of view, it remains difficult to definitely explain the occurrence of this Casuarina at Newport and Otford, though it cannot appeal to one as being the result of accident or coincidence. The suggestion that it may have formed part of the ancient flora and have continued southerly to Victoria partly along the area which now forms the continental shelf seems quite possible and even probable. In view of its suggested antiquity, the question will naturally arise as to why has it not spread across the Hawkesbury Sandstone on to the Wianamatta Shales about 12 to 15 miles away, and which should produce a flora somewhat similar to that of the Narrabeen Shales. Had the distribution been by birds, this would probably have happened long ago. The reason why it is not on the Hawkesbury Sandstone area is probably a geological one.

A. O. Seward, M.A., F.G.S., ${ }^{*}$ quotes Fuchs in reference to the nature of the soil on the character of the vegetation, and in

* Fossil Plants as Tests of Climate. 1902, p.42. 
speaking of the Italian flora says :- " He notes a change from a central European to a Mediterranean flora independent of climate. The occurrence of the Mediterranean flora he considers to depend not so much upon the climate as upon the nature of the surface rocks."

In New South Wales alone we have innumerable instances where the flora changes with a distinct line of cleavage, but in most of such cases it is at the meeting of igneous and sedimentary formations. In the locality under discussion we have sandstone and shale, which are both sedimentary. But there are, at a rough estimate, probably twenty to thirty per cent. of the plants growing on the Hawkesbury Sandstone which do not occur on the Wianamatta Shale, excepting around the fringe or where the shale is shallow and the influence of the sandstone operates. Two well known instances in the case of large trees may be quoted, viz., Eucalyptus corymbosa Sm., the well known Bloodwood, and Angophora lanceolata Cav., the smooth-barked Apple or so-called Red Gum, both of which are common on the sandstone, but practically never on the deep shale. On the other hand, the common Box around Parramatta and Penrith, Eucalyptus hemiphloia F.v.M., is abundant on the Wianamatta Shale, but rarely, if ever, occurs on the Hawkesbury Sandstone. Some of these species are probably as ancient as any of the genus Eucalyptus, and have had thousands of years to spread only a matter of a few yards on to the adjoining formation without having done so. Further enlightenment in regard to plant food may make the reason apparent.

Tracts of isolated but similar vegetation are not uncommon, and an examination of the surrounding country in many cases discloses the fact that these particular floras are growing on the same geological formation which was formerly more extensive, but in intervening areas has been removed by denudation. The presence of trees in distant situations may often be explained by an investigation of former conditions and an imaginary reconstruction of the old land-surface in the locality; or, in other words, outliers may often be more satisfactorily accounted for as ancient remnants than as recent extensions. 
After investigating the various methods of distribution, and having in view the isolated occurrence of Casuarina stricta along the east coast of New South Wales, the suggestion that it formed part of the latest flora on the present continental shelf before its final submergence, seems to me less open to destructive criticism than any other put forward. Such a conclusion is supported by an inspection of the She-oaks now growing on the narrow sloping strip of Narrabeen formation near Otford and Stanwell Park. Here $C$. stricta may be seen creeping up to the foot of the Hawkesbury Sandstone hills, but going no further, its place being then taken by $C$. suberosa Ott. \& Dietr. The contemplation of this patient though persistent progression, especially in the light of our geological knowledge of the past history of this coastal area, suggests that the species has worked its way up from the south along the old land-surface where the formation was found suitable, and on reaching the sandstone, quietly awaited its erosion, in exactly the same way as we find it doing to-day.

I am much indebted to Mr. W. S. Dun, Palæontologist, Mines Department, for references to literature bearing on the subject matter of this paper.

\section{EXPLANATION OF PLATES XII.-XIII.}

Plate xii.

Casuarina stricta Ait., on Narrabeen Shale Formation; Otford to Stanwel Park, N.S.W.

Plate xiii.

Map showing the 100-fathom line on the Coast of South-East Australia.

\section{CENSUS MUSCORUM AUSTRALIENSIUM.}

A classified Catalogue of the Frondose Mosses of Australia and Tasmania, collated from available Publications and Herbaria Records, by the Rev. W. Walter Watts and Thomas Whitelegge, F.R.M.S.

\section{PART II.}

(To be issued separately as a Supplement to Part 4 of this Volume). 


\section{$2 \mathrm{BHL}$ Biodiversity Heritage Library}

Cambage, R. H. 1905. "Notes on the native flora of New South Wales. Part IV. The occurrence of Casuarina stricta Ait., on the Narrabeen shales." Proceedings of the Linnean Society of New South Wales 30, 376-391. https://doi.org/10.5962/bhl.part.12910.

View This Item Online: https://www.biodiversitylibrary.org/item/30106

DOI: https://doi.org/10.5962/bhl.part.12910

Permalink: https://www.biodiversitylibrary.org/partpdf/12910

\section{Holding Institution}

MBLWHOI Library

\section{Sponsored by}

MBLWHOI Library

\section{Copyright \& Reuse}

Copyright Status: NOT_IN_COPYRIGHT

This document was created from content at the Biodiversity Heritage Library, the world's largest open access digital library for biodiversity literature and archives. Visit BHL at https://www.biodiversitylibrary.org. 